\title{
PHARMACOTHERAPEUTIC FOLLOW-UP FORM FOR CAREGIVERS OF PATIENTS WITH REFRACTORY SCHIZOPHRENIA
}

\section{REVIEW ARTICLE}

SILVA, Aglaciene Lopes da ${ }^{[1]}$, BASTOS, Camila Granado de ${ }^{[2]}$, DOMINGOS, Flavia Caires ${ }^{[3]}$, PINTO, Michele Cristina da Rocha ${ }^{[4]}$, SANTANA, Claudinei Alves ${ }^{[5]}$

SILVA, Aglaciene Lopes da. Et al. Pharmacotherapeutic follow-up form for caregivers of patients with refractory schizophrenia. Revista Científica Multidisciplinar Núcleo do Conhecimento. Year 05, Ed. 09, Vol. 05, pp. 93-107. September 2020. ISSN: 2448-0959, Access link: https://www.nucleodoconhecimento.com.br/health/schizophrenia-refractory, DOI: 10.32749/nucleodoconhecimento.com.br/health/schizophrenia-refractory

\section{SUMMARY}

Introduction: Schizophrenia is one of the most relevant mental disorders in public health, causing great distress for the patient and his/her family members. The persistence of symptoms characterizes refractoriness of the disease that is treated with clozapine considered the gold standard in treatment, but its adverse reactions can be as intense as the symptoms of the disorder. Objective: To develop a pharmacotherapeutic follow-up form for caregivers of adult patients with schizophrenia would refract from the use of clozapine. Methods: The search for the articles was carried out in the government databases and websites from November 15, 2018 to January 15, 2019, published from 2012. Result: Thirty-seven articles were found, excluding 20 articles, including in this review 17 articles, 2 books, 4 clinical protocols and 1 drug monograph. Conclusion: The proposal to develop the pharmacotherapeutic follow-up form is to identify adverse reactions that may influence the treatment of pharmacological treatment and reduce the unwanted effects of treatment as a consequence to improve the patient's quality of life. 
Keywords: pharmaceutical care, schizophrenia, clozapine, caregivers.

\section{INTRODUCTION}

Schizophrenia or schizophrenic disorders constitute a group of severe mental disorders, without pathognomonic symptoms, characterized by distortions of thought and perception, by inadequacy and difficulty in expressing affection without prejudice to intellectual capacity, presenting cognitive impairments over time (PEREIRA et al., 2013)

They are characterized by the presence of positive symptoms (delusions, hallucinations and disorganization of thought and conduct, bizarre ideas, psychomotor agitation and language disorders) and negative symptoms (affective-volitional dullness), cognitive losses (especially deficit of the capacity for abstraction and insight) and depressive and anxious symptoms. (CEZARETTO et al., 2014)

The first episode is presented in the form of a psychotic episode, around 20 years, in men and 25 in women, usually associated with hallucinations, delusions and disorganization of thought during acute crises; interspersed by periods of remission, with difficulty in expressing emotions, apathy, social isolation and a deep feeling of hopelessness. (SILVA et al., 2016)

Schizophrenia is one of the most important mental disorders in public health, causing great distress for the patient and his/her family members. (MAGALHÃES et al., 2018) About $30 \%$ of people who have schizophrenia then show improvement in the clinical picture, being called refractory to treatment, and the main characteristic of Refractory Schizophrenia is the persistence of positive symptoms of moderate to severe intensity, despite the appropriate treatment (PEREIRA et al., 2013; CEZARETTO et al., 2014). According to the World Health Organization (WHO) in 2018 it was estimated that there were 21 million people with schizophrenia in the world, causing an important cognitive, functional and affective impact (PEREIRA et al., 2013; WHO, 2019).

In Brazil in 2008, approximately 1.6 million schizophrenic patients were estimated to be in Brazil, impacting the health system by demanding specific assistance. (Oliveira et al., 2017) 
The treatment of schizophrenia is composed of drug therapy (antipyycotic), psychotherapy and sociotherapy. (FREITAS et al., 2016)

Antipsychotic drugs are antagonists or partial agonists in dopamine D2 receptors, but most also block several other monoamine receptors. The potency of antipyysycs, in general, runs parallel to the activity of D2 receptors, but activities in other receptors (5HT2A, and muscarinics) can reduce adverse extrapyramidal effects. (RANG et al., 2007)

Antipsychotics may also be divided into typical antipsychotics (haloperidol, flupazine, primozide, chlorpromazine, levomepromazine) i.e., older drugs with prominent actions in the D2 receptor, and atypical antipsychotics (clozapine, olanzone, quetiapine, zipraside and risperidone, which constitute a younger generation of drugs with less prominent D2 antagonism and consequently with fewer extrapyramidal effects. (GOLAN, 2009)

Treatments should be done in monotherapy according to the safety profile and tolerability of the patient (CEZARETTO et al., 2014). In case of therapeutic failure with the use of any of these drugs for at least 6 weeks at appropriate doses without improvement of at least $30 \%$ in the Psychiatric Evaluation scale, a second attempt with some other antipsychotic should be made (BRASIL, 2013).

For patients who have the most severe form of schizophrenia, called refractory or resistant, the treatment of choice is the use of atypical antipsychotic, clozapine, considered the gold standard in which it demonstrates to reduce acute symptoms and the risk of suicide (FREITAS et al., 2016; CAMPANA E SOARES, 2015). Having no evidence that the association with another antipsychotic may bring benefits to the patient (PEREIRA et al., 2013).

All antipsychotics, with the exception of clozapine, can be used in treatment without order of preference in patients diagnosed with Schizophrenia (BRASIL, 2013).

For the control of schizophrenia, drug treatment is essential, but in the evaluation of patients, adverse reactions caused by drug treatment can be as intense as the symptoms of the disorder, which are extrapyramidal motor changes, endocrine changes, sedation, hypotension and weight gain, dry mouth, blurred vision, agranulocytosis (SILVA et al., 2016; GOLAN et al., 2009). 
The World Health Organization defines adverse drug reaction (AR) as "any harmful or undesirable and unintended response that occurs with drugs in doses commonly used in men for prophylaxis, diagnosis, treatment of disease or modification of physiological functions" (WHO, 2019).

The family becomes a protagonist in the care of people with schizophrenia being important for their resocialization and, therefore, it is the first and main social institution with which the mentally ill person will socialize (BENNETT et al., 2015; CAMPANA E SOARES, 2015). It is important that their caregivers and family members are prepared to live with the pain and suffering of the patient (CEZARETTO et al., 2014; MAGALHÃES et al., 2018).

One of the main concerns of mental health care is polypharmacy with exaggerated and inadequate use of medications, which can be adapted by the care, care or clinical activity of the pharmacist (FEGADOLLI et al., 2016). The participation of the pharmacist has been fundamental, being able to establish the first contact with the patient and act as a link with the other professionals of the mental health team participating in strategies of adhering and adverse reactions acting in mental health care (MAGALHÃES et al., 2018; FEGADOLLI et al., 2016; SILVA E LIMA, 2017).

\section{GOAL}

Developing a pharmacotherapeutic follow-up form for caregivers of adult patients with schizophrenia would refract from the use of clozapine.

\section{METHODOLOGY}

The search for the articles was carried out in the databases: Scielo (Scientific Electronic Library Online) and PubMed (National Library of Medicine), NCBI (National Center for Biotechnology Information), VHL (Virtual Health Library), government websites (Ministry of Health, National Health Surveillance Agency, World Health Organization) in Portuguese and English. The search was conducted from November 15, 2018 to January 15, 2019. 
The key words used in Portuguese were pharmaceutical attention, schizophrenia, clozapine and caregivers and in English pharmaceutical attention, schizophrenia, clozapine and caregivers.

Articles published from 2013 to 2018 with free access and full text were considered valid.

\section{RESULTS}

From the methodology adopted, 37 articles were found that after exhaustive reading were excluded 20 articles, because they did not demonstrate clarity in the proposed theme.

Thus, 17 articles, 2 books, 4 clinical protocols and 1 monograph of the drug were included in this review.

\section{DISCUSSION}

Adverse drug reactions (ADR) are more common than can be expected and can never be guaranteed that a medicine is completely safe. The use of medicines in situations not indicated or in circumstances that violate the criteria of rational use can cause harm, increase the frequency of hospitalizations, health costs and even death.

Clozapine is the treatment of choice in refractory schizophrenia and its therapeutic effect promotes an improvement of logical reasoning, an essential situation for understanding the disease and treatment adhering, thus resulting in an important clinical improvement of patients and, consequently, of their quality of life (BARKHOF et al., 2012; BATISTA et al., 2016; SISKIND et al., 2016).

However, the use of clozapine is not free from adverse effects, some of which are potentially life-threatening, are important limitations for non-adherence (PORRASSEGOVIA et al., 2017). Concerns about other adverse effects that include, lack of appetite, sedation, weight gain, insulin resistance, which are related to the development of metabolic syndrome (MS) and strong intrinsic anticholinergic activity may increase resistance to try this medication (BATISTA et al., 2016; SISKIND et al., 2016; PORRAS-SEGOVIA et al., 2017). 
The presence of a relative or individual responsible for caring for the patient should be considered, helping to perform daily activities, since the severity of the disease generates stress, isolation and additional financial costs, making caregivers overloaded (KHAN AND ZAIDI, 2017; HANSEN et al., 2014).

In relation to clozapine, an adverse reaction of important impact on the patient is agranulocytosis, characterized by the decrease in granulocitic white cells being one of the main reasons for discontinuation of treatment (SISKIND et al., 2016; KHAN E ZAIDI, 2017). This risk for agranulocytosis has a prevalence of $1-2 \%$ in patients treated with clozapine, a situation mandatorily monitored by health professionals to ensure that patients receive the drugs routinely (WARNEZ And ALESSI-SEVERINI, 2014). Current product monographs determine that patients start therapy gradually and that leukocyte and neutrophil (LAN) counts are maintained at safe levels (CRISTALIA, 2019).

For the follow-up of the patient and his caregiver, a pre-pharmacotherapeutic followup form was prepared with very common and common ADR of clozapine, initially selected because they are reactions that are in more evidence in clinical studies, are easier to identify, and because they are reasons for further treatment withdrawal. Other ADR of the drug were not used because they required specialized medical attention and laboratory test results.

From the literature review, the mandatory fields present in the pharmacotherapeutic follow-up form presented below were selected:

- Patient identification: In this block, the patient's characteristics are identified regarding name, gender, date of birth, age anthropometric measurements (height and weight). Weight assessment is important, because one of the adverse reactions is the weight gain that is related to Metabolic Syndrome (MS) (BATISTA, 2016). There is evidence that people with refractory schizophrenia using clozapine are exposed to a higher risk for MS compared to schizophrenia in general, and may reach twice the weight, representing a serious public health problem worldwide (BATISTA, 2016).

- Clinical condition of the patient: This block identifies the limitations of the patient regarding vision, speech, locomotion and hearing. If there is some limitation, the presence of a caregiver will be necessary. 
- Lifestyle habits and addictions: Alcohol consumption, cigarette use and illicit drugs are identified: This information is important because clozapine potentiates the effects of alcohol and other central nervous system depressants, and if the patient is a smoker, sudden cessation of smoking increases the plasma concentration of clozapine, leading to an increase in adverse reactions (CRISTALIA , 2019)

- Eating habits and physical activity: This block identifies the daily frequency of feeding and physical activity in order to intervene to improve the patient's quality of life, since caffeine intake can increase the plasma concentration of clozapine (CRISTALIA, 2019).

- History of drug use and allergies: This block identifies the history of use and allergies to other medications in order to minimize the harmful effects drug interactions.

- Drug treatment with clozapine: This block identifies daily doses and times of administration in order to minimize the harmful effects of drug interactions.

- Evaluation of treatment adhering: In this block, it seeks to identify whether the patient presents difficulties in the treatment's adhering to the treatment in order to guide him/her with the correct use for a greater therapeutic effect.

- Evaluation of Adverse Drug Reactions (ADR's): In this block the patient and/or caregiver will indicate the presence of some adverse reaction to the drug describing its frequency.

Table 1. Common and Very Common Adverse Drug Reactions separated by physiological systems (CRISTALIA, 2019).
Disturbance
by
physiological system
Common ADR
Metabolic and nutritional
disorders
Psychiatric disorders
Weight gain
Dysarthria (muscle weakness, difficulty speaking)

Very common ADR 


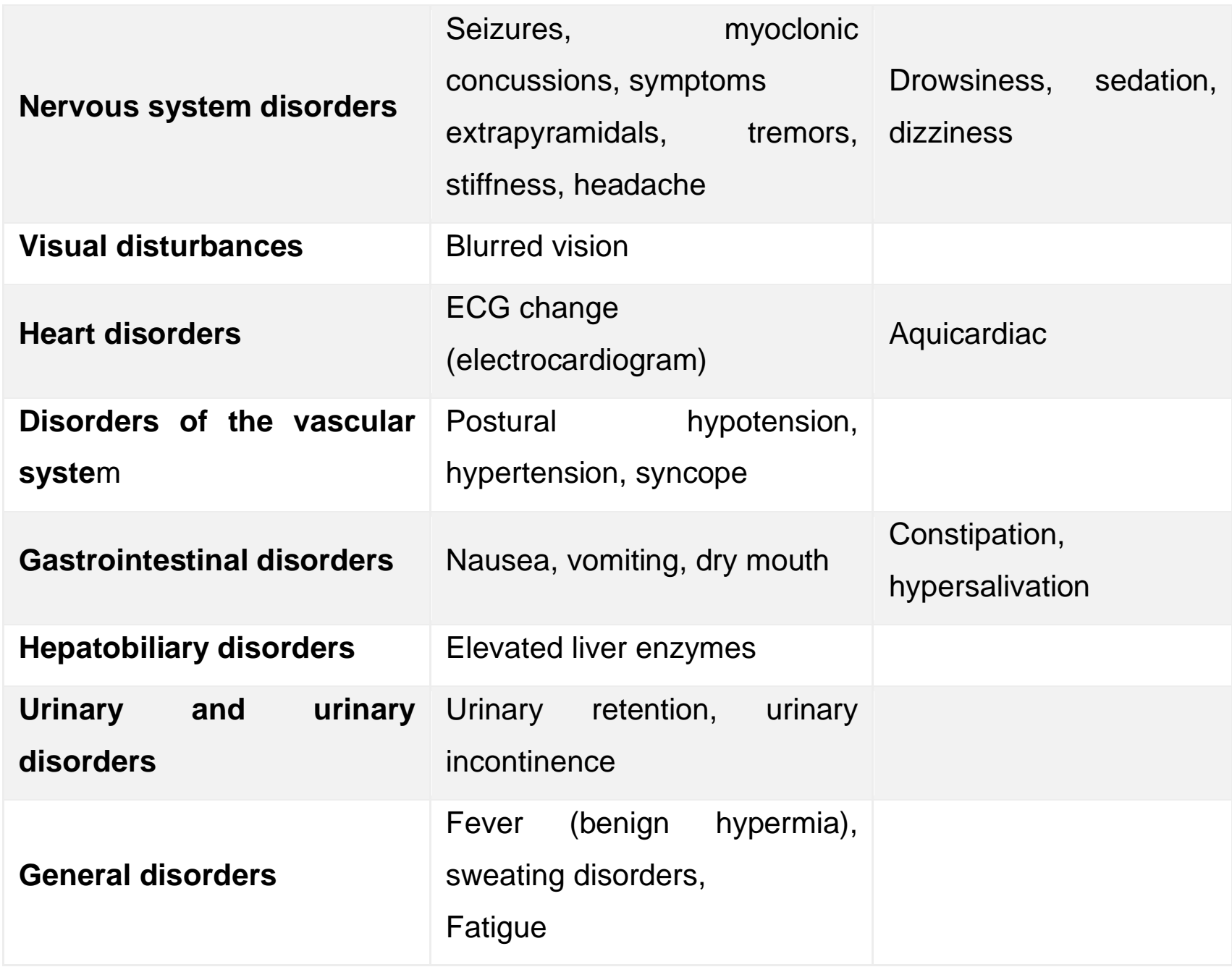

Source: Own elaboration

- Identification of the person responsible for the filling: the patient or caregiver.

- Pharmaceutical Conduct: In this field will be determined the conduct and pharmacotherapeutic guidelines to be transmitted to the patient or caregiver to improve the quality of life of the patient. 
Figure 1. Pharmacotherapeutic Follow-up Form of Patients using Clozapine (BRASIL, 2019; CFF, 2019) Pharmacotherapeutic Follow-up Form of Patients using Clozapine

Patient Name: Gender:

Nasc.:___ Date

$$
\text { Has any limitations ( ) Yes, which? () No }
$$

Vision () Speech ( ) Locomotion () Hearing ()

Smoker ( ) SiM ( ) Not Quant.cigarro/dia

Do you use Alcohol ( ) Yes ( ) Not What frequency? times a week

Do drugs use () Yes, which? () Do not describe

Eating Habits: What meals do you eat daily/ schedule?

Do drugs use () Yes, which? () Do not describe

Eating Habits: What meals do you eat daily/ schedule?

\begin{tabular}{c|c|c|c|c|c|} 
Breakfast & $\begin{array}{c}\text { Morning } \\
\text { snack }\end{array}$ & Lunch & $\begin{array}{c}\text { Afternoon } \\
\text { snack }\end{array}$ & Dinner & $\begin{array}{c}\text { Evening } \\
\text { supper }\end{array}$
\end{tabular}

Food

Types: 


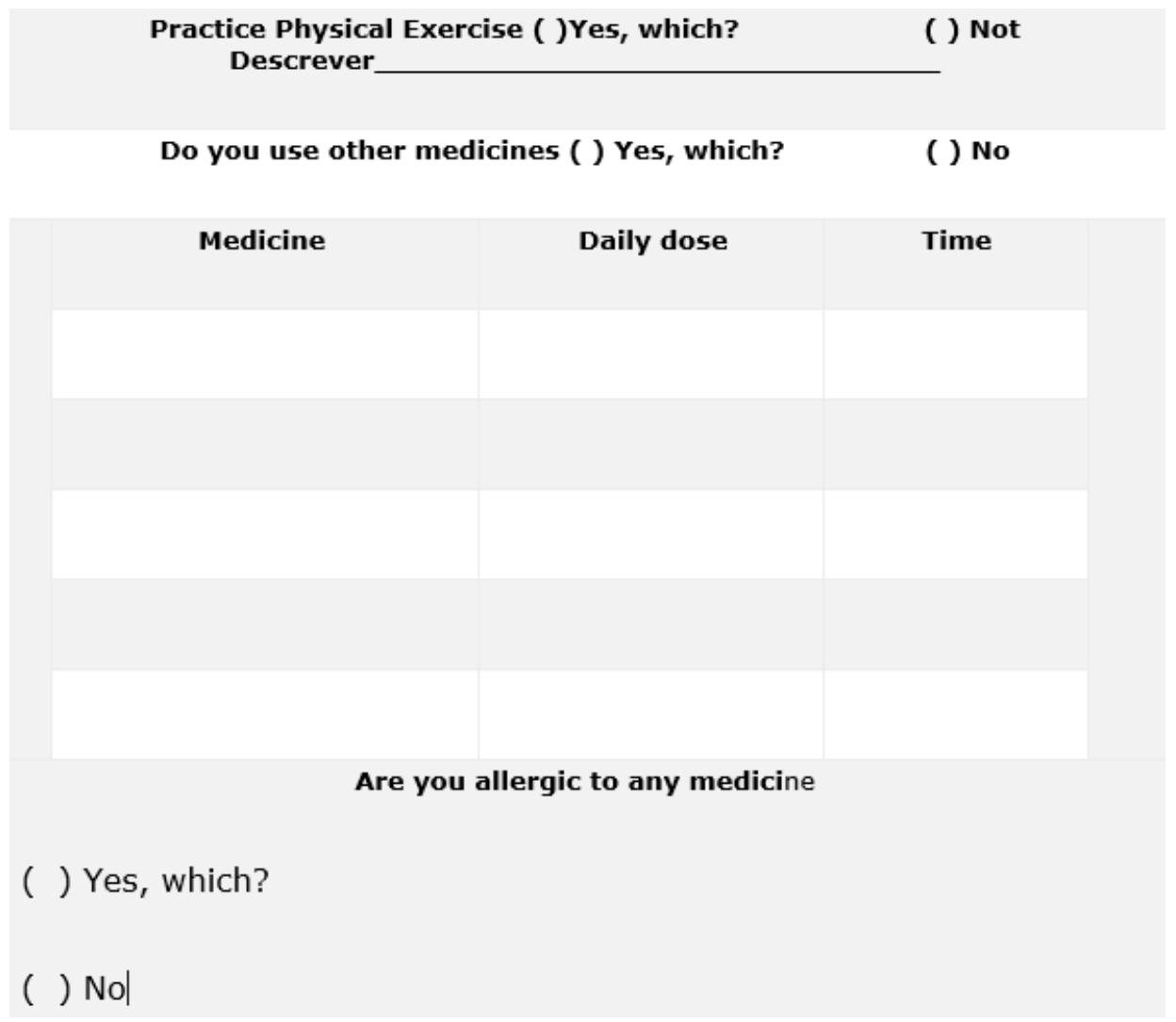

RC: 62622

Disponível em: https://www.nucleodoconhecimento.com.br/health/schizophrenia-refractory 


\section{Current Treatment}

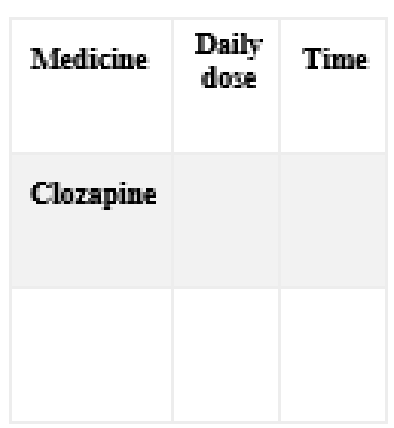

Treatment Adhering Assessment

Have difficulty taking the tablet ( ) Yes, which ( ) No Describe

Have you forgotten to take the pill? ( ) Yes ( ) No
Is the medicine taken at the indicated time? ( ) Yes ( ) No
When you feel any discomfort, do you stop taking the medicine? ( ) Yes ( ) No
When you feel vell, do you stop taking your medicine? ( ) Yes ( ) No
Evaluation of Adverse Drug Reactions (ADR)
Was there weight gain after the start of treatment? ( ) Yes ( ) No Weight
anterior__urrent Weight
Previous PA




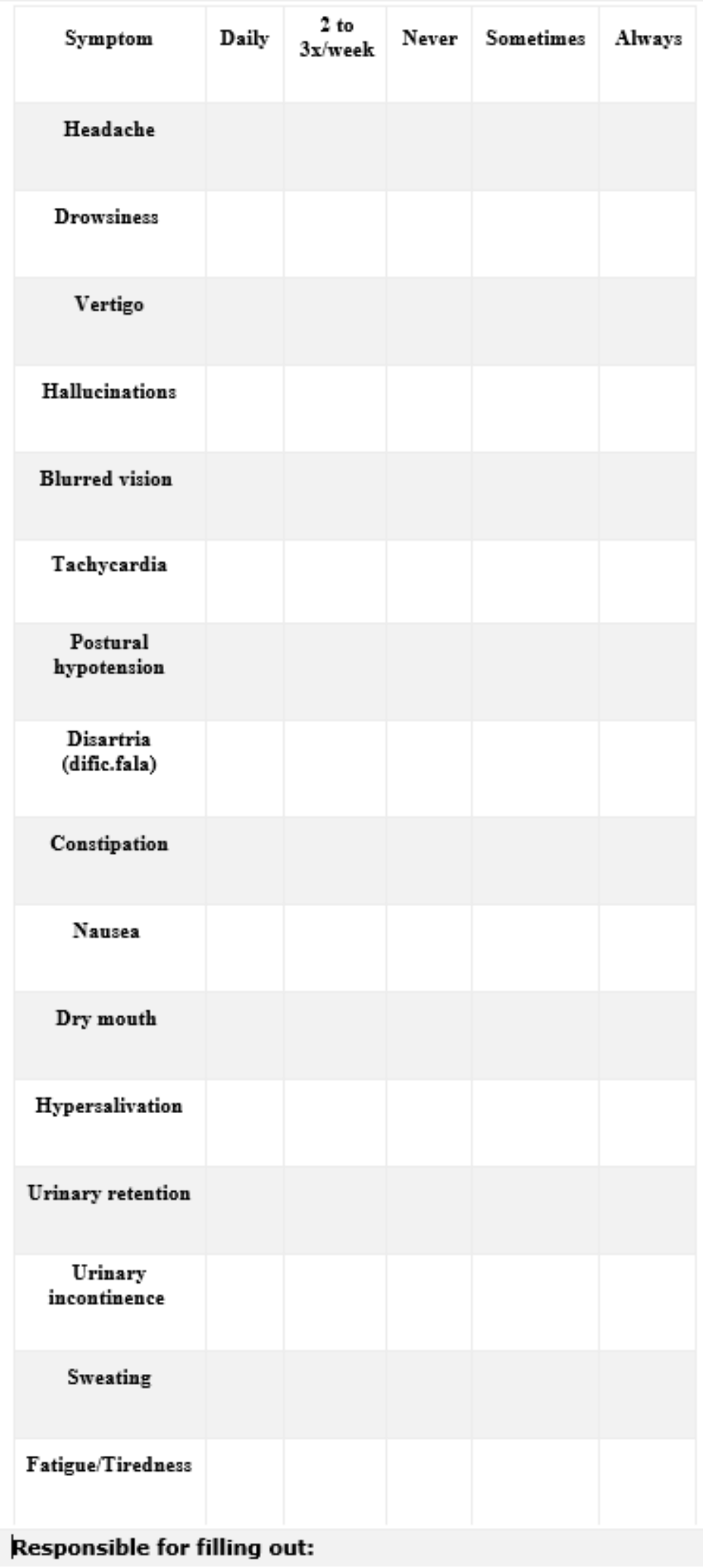

Source: Own elaboration

RC: 62622

Disponível em: https://www.nucleodoconhecimento.com.br/health/schizophrenia-refractory 
The proposed pharmacotherapeutic follow-up form aims to improve treatment and be a quick and possible tool to be applied by patients and family members and/or caregivers without specific knowledge of the pathology.

\section{CONCLUSION}

The proposal to elaborate the pharmacotherapeutic follow-up form is to identify adverse reactions that may influence treatment's treatment and reduce the unwanted effects of treatment as a consequence of improving patient quality of life.

For the patient, the elaboration of this form means a possibility of safer and more efficient care by the pharmacist, since it allows the rescue of the history of the events experienced by him as a result of the use of the drug.

Existing information records can dispense with or simplify additional inquiries and exams, reducing hospitalizations, medical interventions and length of stay in health services due to adverse reactions.

In relation to health professionals, the recording of this information may contribute to the integration of the health team, enabling the coordination of care. In teaching and research, it allows the knowledge of adverse reactions, history of medications used, limitations or health problems promoting greater knowledge and interventions on the subject.

In patient care, the pharmacist can guide you on the correct use of prescribed medications, with the intention of improving therapeutic effects and reducing the likelihood of onset of adverse reactions, drug interactions and toxicity.

This process brings great benefits and provides greater professional recognition to the pharmacist, strengthening the bond in health actions in the follow-up of patients with refractory schizophrenia.

\section{REFERENCES}

BARKHOF, Emile et al. Interventions to improve adherence to antipsychotic medication in patients with schizophrenia-a review of the past decade. European Psychiatry, v. 27, n. 1, p. 9-18, 2012. 
BATISTA, FPH et al. Prevalencia de síndrome metabólico en pacientes con esquizofrenia refractaria. Ciencia y enfermería, v. 22, n. 3, p. 11-24, 2016.

BENNETT LMD et al. Patients' preferences related to benefits, risks, and formulations of schizophrenia treatment. Psychiatric Services, v. 66, n. 7, p. 719-726, 2015. BRASIL. Ministério da Saúde. Portaria SAS/MS o 364, de 9 de abril de 2013. Protocolo clínico e diretrizes terapêuticas de esquizofrenia. Disponível em $<\quad$ http://portalarquivos.saude.gov.br/images/pdf/2014/abril/02/pcdt-esquizofrenialivro2013.pdf> Acesso 15.nov.18 ás16h.

BRASIL. Portal da saúde. Formulário padronizado para realização da consulta farmacêutica. Disponível em <http://portalsaude.saude.gov.br/images/docx/2015/abril/16/FORMUL-RIOPADRONIZADO-PARA-REALIZA-O-DA-CONSULTA-FARMAC-UTICAdisponibilizado-no-site.docx> Acesso 15.jan.19 ás 15h. BRASIL. Conselho Federal de Farmácia. Modelo de formulário para documentação de serviços clínicos. Disponível em: http://www.cff.org.br/noticia. php?id=2581\&titulo=CFF+disponibilizamodelos+de+form ul\%C3\%A1rios+para+documenta\%C3\% A7\%C3\%A3o+de+servi\%C3\%A7os+cl\%C3\%ADnicos> Acesso 15.jan. 19 ás 14h CAMPANA, Mariana Campos; SOARES, Marcos Hirata. Familiares de pessoas com esquizofrenia: sentimentos e atitudes frente ao comportamento agressivo. Cogitare Enfermagem, v. 20, n. 2, 2015.

CEZARETTO, Marceli et al. Perfil clínico e sociodemográfico de pacientes com esquizofrenia refratária tratados em um centro terciário. Jornal Brasileiro de Psiquiatria, v. 63, n. 3, p. 185-190, 2014.

CLOZAPINA medicamento genérico. Jose Carlos Módolo. São Paulo.Cristalia. Disponível em: <http://www.anvisa.gov.br/datavisa/fila_bula/frmVisualizarBula.asp?pNuTransacao=1 175432015\&pldAnexo=2444983> Acesso em 15.nov.18 ás $20 \mathrm{~h}$.

FEGADOLLI, Claudia et al. Farmacêuticos integrando equipes de cuidado em saúde mental no Sistema Único de Saúde (SUS): uma reflexão coletiva na cidade de São Paulo. Interface-Comunicação, Saúde, Educação, v. 20, p. 1093-1098, 2016. 
FREITAS, Pedro Henrique Batista de et al. Esquizofrenia refratária: qualidade de vida e fatores associados. Acta Paulista de Enfermagem, v. 29, n. 1, p. 60-68, 2016. FREITAS, PHB; NUNES, FDD; PINTO, JAF; et al. Síndrome metabólica em pacientes com esquizofrenia. Rev. enferm. Cent.-Oeste Min, 2016, 6(1):1976-1993. Disponível em: http://pesquisa.bvsalud.org/enfermagem/resource/pt/bde-28449> Acesso 10.dez.18 ás 20h.

GOLAN, DE; TASHJIAN, AH; ARMSTRONG, EJ; et al. Princípios de Farmacologia: a Base Fisiopatológica da Farmacoterapia, 2ed. Rio de Janeiro, Guanabara Koogan, 2009, 177-180.

KHAN, Afaque H.; ZAIDI, Samina. Clozapine: improvement of negative symptoms of schizophrenia. Cureus, v. 9, n. 12, 2017.

HANSEN, Nayara Fernanda et al. A sobrecarga de cuidadores de pacientes com esquizofrenia: uma revisão integrativa da literatura. Revista eletrônica de enfermagem, v. 16, n. 1, p. 220-7, 2014.

MAGALHÃES, Josiléia Félix et al. Estratégias de enfrentamento de mulheres cuidadoras de pessoas com esquizofrenia. Revista de Pesquisa: Cuidado é fundamental online, v. 10, n. 3, p. 793-800, 2018.

OLIVEIRA, DPA; LEITE, ESM; ARAUJO, GM, et al. Vivências e qualidade de vida de portadores de esquizofrenia. Journal of Medicine and Healt Promotion, 2017, 2(3):535-543. Disponível em http://jmhp.fiponline.edu.br/pdf/cliente=13de8b335b0a80db19c7acdd64fe02483c.pdf> Acesso 26.nov.18 ás 21h.

PEREIRA, ADU; MUSSEL, E; BARROS, HL, et al. Protocolos Clínicos e Diretrizes Clinicas, Esquizofrenia Refratária. Fundação Hospitalar do Estado de Minas Gerais, 2013, (30):101-130. Disponível em <http://www.fhemig.mg.gov.br/index.php/docman/Proto colos_Clinicos-1/126-030esquizofrenia-refrataria-07082014/files> Acesso:15.nov.18 ás 16h PORRAS-SEGOVIA, Alejandro et al. Rapid-onset clozapine-induced loss of glycaemic control: case report. BJPsych open, v. 3, n. 3, p. 138-140, 2017.

RANG, H.P; DALE, M.M; RITTER, J.M, et al. Farmacologia, 6ed. Rio de Janeiro, Elsevier, 2007, 551-553. 
SILVA, Sarah Nascimento; LIMA, Marina Guimarães. Assistência Farmacêutica na Saúde Mental: um diagnóstico dos Centros de Atenção Psicossocial. Ciência \& Saúde Coletiva, v. 22, p. 2025-2036, 2017.

SILVA, Amanda Mendes et al. Esquizofrenia: Uma revisão bibliográfica. UNILUS Ensino e Pesquisa, v. 13, n. 30, p. 18-25, 2016.

SISKIND, Dan et al. Clozapine v. first-and second-generation antipsychotics in treatment-refractory schizophrenia: systematic review and meta-analysis. The British Journal of Psychiatry, v. 209, n. 5, p. 385-392, 2016.

WARNEZ, Stephanie; ALESSI-SEVERINI, Silvia. Clozapine: a review of clinical practice guidelines and prescribing trends. BMC psychiatry, v. 14, n. 1, p. 1-5, 2014. WHO. Organização Mundial de Saúde. Esquizofrenia. Disponível em $<$ https://www.who.int/topics/schizophrenia/es/> Acesso 13.dez.18 às 20h40min. (2019)

${ }^{[1]}$ Pharmaceutical. Specialist in Clinical Pharmacology and Pharmacotherapy, Senac.

${ }^{[2]}$ Pharmaceutical. Specialist in Clinical Pharmacology and Pharmacotherapy, Senac.

${ }^{[3]}$ Pharmacist. Specialist in Clinical Pharmacology and Pharmacotherapy, Senac.

${ }^{[4]}$ Pharmaceutical. Specialist in Clinical Pharmacology and Pharmacotherapy, Senac.

[5] Pharmacist. Master in Medical Sciences, FMUSP. Multiprofessional Oncology Specialist (HSL). Specialist in Hospital Pharmacy (FOC).

Submitted: August, 2020.

Approved: September, 2020. 